原藷

ヒト内リンパ襄直流電位（ESP）の測定

隈上 秀高 ${ }^{12)}$ ・奥 竜太 ${ }^{2)}$ ・田中 藤信 ${ }^{2)}$

重野浩一郎 2 ・高橋 啨雄 ${ }^{22}$

\title{
Measurement of Human Endolymphatic Sac Potential
}

\author{
Hidetaka Kumagami ${ }^{12)}$, Ryota Oku ${ }^{2)}$, Fujinobu Tanaka ${ }^{2)}$, \\ Koichiro Shigeno ${ }^{2)}$, Haruo Takahashi ${ }^{2)}$ \\ ${ }^{1)}$ Department of Otolaryngology, Ureshino National Hospital \\ 2) Division of Otorhinolaryngology, Department of Translational Medical Sciences, \\ Nagasaki University Graduate School of Biomedical Sciences
}

In this study we measured human Endolymphatic Sac Potential (EPS) in 8 patients with acoustic neuroma during the translabyrinthine removal of the tumor. EPS was measured with a glass electrode filled with $154 \mathrm{mM} \mathrm{NaCL}$ and with an outside tip diameter ranging from 2 to $3 \mu \mathrm{m}$. The mean value of ESP in patients with acoustic neuroma was $+13.3 \pm 1.9 \mathrm{mV}$. To our knowledge, our study was the first successful measurement of human ESP.

Key words: EPS, human endolymphatic sac, acoustic neuroma

\section{はじめに}

内リンパ震を機能の観点よりみると, (1)内リン パ吸収123，(2)内耳の免疫防御能3)，(3)利尿ホルモ ン産生 ${ }^{4)}$, (4)内耳王調節), (5)イオン調節能6) など がこれまで報告されている。一般に，ある器官に 打いて，その特有の機能維持のため，あるいは器 官自体の活動の結果としての電位が観察され, 内 耳では音情報の機械電気変換に蝸牛内リンパ直流 電位 (Endocochlear Potential: EP) は不可欠とさ れる。内りンパ囊に括いても固有の直流電位が存 在することが知られて抢り, 内リンパ囊植流電位 (Endolymphatic Sac DC Potential: ESP) と呼ばれ ている。1983年，モルモットに拈いて，硬膜外了

\footnotetext{
1) 国立嬉野病院耳鼻咽喉科

2) 長崎大学医歯薬総合研究科病態解析制御学請座 耳鼻咽喉病態制御学領域
}

プローチにより Amano ら7)が初めて ESP 測定に 成功した。以来, その存在と特徵は, 動物実験に より確䜑されてきた。一方，ヒト内リンパ囊の研 究は，主として電顕，免疫組織学的手法を用いた 形態学的な観点よりなされ, 電気生理学的手法に よる検討は少なく，これまでヒト内リンパ囊に関 する ESP 測定の報告はない。今回，我々は，正 常ヒト ESP の值を知り, 将来的にメニエール病 患者の ESP と比較検討することを目的とし，経 迷路法による聴神経腫痬摘出手術の際，ESP 测 定を試みた。

\section{対象と方法}

1998年から2002年までの期間，長崎大学耳鼻咽 喉科にて経迷路法による聴神経腫瘍摘出術を施 行された症例中の 8 例を対象とした。測定に先 立ち，経迷路法による手術では迷路を削除するた めに内リンパ襄の操作では術後平衡障害に大きな 
影響がない点，および将来的にはメニエール病患 者の ESPと比較することによりメニエール病患 者の病態解明に寄与できる可能性について患者, 家族には十分な説明を行い承諾を得た。また，学 内倫理委員会, ヘルシンキ宣言についても十分検 討, 照合し承諾を得た。症例は男性 1 名，女性 7 名, 年齢は42歳〜 74歳（平均62.3歳）であった。 全例患耳一側性の感音性難聴を呈し各症例の 4 分 法による平均聴力は $41.0 \mathrm{~dB}$ 襲で, 症例全体の 平均は $72.5 \mathrm{~dB}$ であった。また 8 例中 6 例の経過 中にめまいの自覚を認めたが，手術直前には全例 めまい・平衡障害はなかった。平衡機能検查では 暗所開眼下の頭位眼振娭査で健側向き水平回旋混 合性眼振を 3 例飞認め, 温度眼振検査では全例患 側耳の CP を呈した。蝸電図検査との他神経耳科 的検查では内リンパ水腫を示唆する所見はなかっ た。ESP の測定は全例，全身麻酔下に乳突削開 術を施行し，続いてメニエール病に対する内リン パ襄手術に準じ内リンパ震硬膜部を露出した後, 迷路削開（labyrinthectomy）前に行われた。測定 用電極として $150 \mathrm{mM} \mathrm{NaCl} て ゙$ 充たしたガラス電 極（先端径 $2 \sim 3 \mu \mathrm{m}$ ） を使用した。不関電極は $\mathrm{Ag}-\mathrm{AgCl}$ を用い, 術創筋上に置いた。電極をマニ ピュレーターに設置し, 徐々に内リンパ雍表面に 接近させ，完全に内リンパ衰に接地し電位が安 定した点を基準点（電位 $0 \mathrm{mV}$ ）とした。さらに 電極を刺入させ ESP 電位を測定した。ESP 電位
は, 微小電極増幅器（FD223, WPI）で増幅後, レコーダー（SR6335，Graphtec）にて記録した。 測定は各症例ごとに 5 回行い，平均値をその症例 のESPとした。測定後, 内リンパ襄の一部を生 検し，その形態を走査電子顕微鏡（JSM-35）にて 観察した。内リンパ褰組織は $2 \%$ タンニン酸を含 む $1 \%$ グルタールアルデヒドにて 2 時間固定し $2 \%$ 四酸化オスミウム， $0.1 \mathrm{M}$ カコジル酸緩衝液 にて 4 時間処理し，上昇エタノール系列にて脱水 した。続いて，臨界点乾燥を行った後，金スパッ タコーティングを行い，走查電顕を用いて観察し た。

\section{結 果}

全例手術終了後, 通常の手術時之同様に覚醒し, 問題となる合併症はなかった。また，ESP 測定 前後で血王，脈拍などの大きな変動はなく全身 循環動態は安定していた。ESP 測定は硬膜上の 内リンパ震遠位部にて行われ，刺入はほぼ一定の 部位で実施し，ESP 值の刺入部位による大きな 変動は認めなかった。ESP の測定値は +10.3土 $2.1 \mathrm{mV} \sim+16.2 \pm 2.1 \mathrm{mV}(\mathrm{n}=8$, 平均士標準偏 差）の値を記録し，その平均は $+13.3 \pm 1.9 \mathrm{mV}$ であった。測定例のまとめを表 1 ，測定の様子を 図 1， ESP の波形例を図 2 飞示す。内りンパ囊 はメニェール病患者にみられるよらな発育不良や 血管分布が減少した所見はなく，全例剥離容易で 色調も注济正常と思われた。内リンパ裹は測定部

表 1 聴神経腫瘍症例と内りンパ霅直流電位（ESP）

\begin{tabular}{|c|c|c|c|c|c|c|c|c|}
\hline 症例 & $\begin{array}{l}\text { 年魿 } \\
\text { (歲) }\end{array}$ & 性別 & $\begin{array}{c}\text { 平均聴力 } \\
\text { (dB) }\end{array}$ & めまい & 眼振 & $\begin{array}{c}\text { 温度眼振穓査 } \\
\text { (患側耳) }\end{array}$ & 走查䉓顕 & $\begin{array}{l}\text { ESP } \\
(\mathrm{mV})\end{array}$ \\
\hline 1 & 48 & 男 & 66.8 & 有 & $\begin{array}{l}\text { 無 } \\
\end{array}$ & $\overline{\mathrm{CP}}$ & 正常 & $+13.5 \pm 1.5$ \\
\hline 2 & 66 & 女 & 72.5 & 有 & 有 & $\mathrm{CP}$ & 正常 & $+13.2 \pm 1.3$ \\
\hline 3 & 74 & 女 & 68.3 & 無 & 無 & $\mathrm{CP}$ & 正常 & $+13.8 \pm 1.8$ \\
\hline 4 & 70 & 女 & 68.3 & 有 & 無 & $\mathrm{CP}$ & 正常 & $+10.3 \pm 2.1$ \\
\hline 5 & 42 & 女 & 95.0 & 有 & 有 & $\mathrm{CP}$ & 正常 & $+11.3 \pm 1.9$ \\
\hline 6 & 65 & 女 & 63.0 & 有 & 無 & $\mathrm{CP}$ & 正常 & $+16.2 \pm 2.1$ \\
\hline 7 & 69 & 女 & 41.0 & 無 & 無 & $\mathrm{CP}$ & 正常 & $+15.3 \pm 2.2$ \\
\hline 8 & 65 & 女 & 曋 & 有 & 有 & $\mathrm{CP}$ & 正常 & $+12.7 \pm 1.9$ \\
\hline 平均 & 62.3 & 1 & 72.5 & 1 & 1 & 1 & 1 & $+13.3 \pm 1.9$ \\
\hline
\end{tabular}




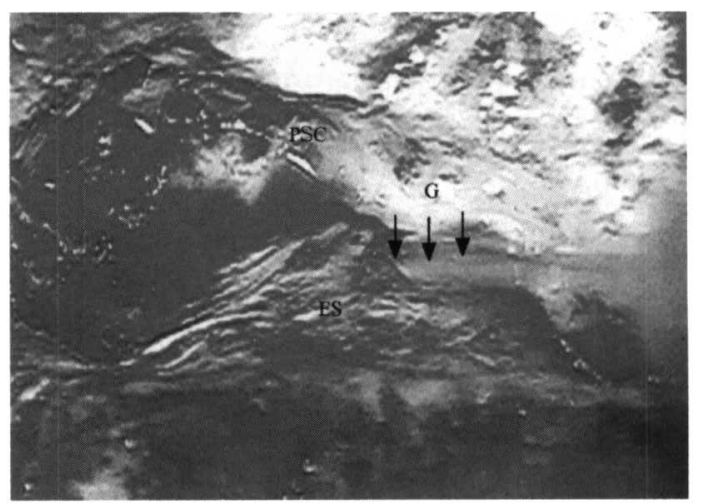

図 1 内リンパ衰直流電位 (ESP) 測定の様子 $\mathrm{ES}$ ：内リンパ襄, $\mathrm{G}$ (矢印)：ガラス電極 PSC : 後半規管。

位を含む遠位部を採取し, 走査電顕にて観察した。 走査電顕では, 細胞表面に微絨毛を有した扁平, 多角形の内リンパ裹上皮が観察され, 表面構造上, 全例ほぼ正常の細胞形態が保たれていた（図 3 )。

\section{考察}

ESP は1983年の $\mathrm{Amano}^{7)}$ の報告以来, 専ら動 物において測定がなされており，+10〜+20 mV 前後の值が記録されている7 99)。これまでヒトに 打ける ESP 測定の報告はなかったが, 今回, 我々 が測定したヒトに打ける ESP の測定值も+13.3 $\pm 1.9 \mathrm{mV}$ と過去, 動物において測定されたもの とほ添同様の結果となった。

形態学的にみると, 聴神経腫瘍の内リンパ衰を 正常コントロールとすることには議論のあるとこ

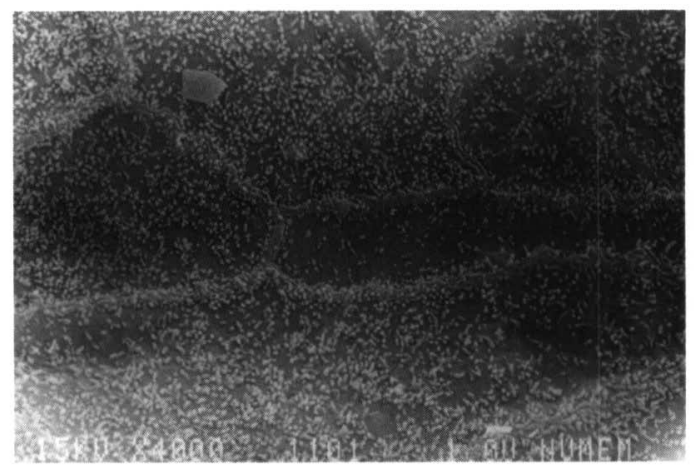

図 3 内リンパ裹の走査電顕所見

表面に豊富な徽綫毛を有した扁平, 多角形 の上皮細胞が観察される。

ろであるが10) 12)，今回，測定の対象とした聴神 経腫瘍 8 例の内リンパ囊に打ける上皮細胞の形態 はよく保たれており，正常の内リンパ裹上皮と考 えられる。従って, 我々が測定した ESP 值は概ね, ヒト ESPの正常值と近似した值と思われる。

また，ESPの測定に際し，技術的には電極周 囲の出血を避け，電極を振動させないことが重要 であるが，さらに迷路削開の影響も考慮するべき である。実験的観察では ESP に対して迷路削開 による急性的な影響はないと思われるが1314)，今 回の測定ではヒトにおける迷路削開が内リンパ裹 に及ぼす影響は不明であり，その影響を避けるた め迷路削開の前に ESP を測定した。

さらに, ESP について電気生理学観点よりみ ると, 内耳に存在する固有の電位の中で ESP は

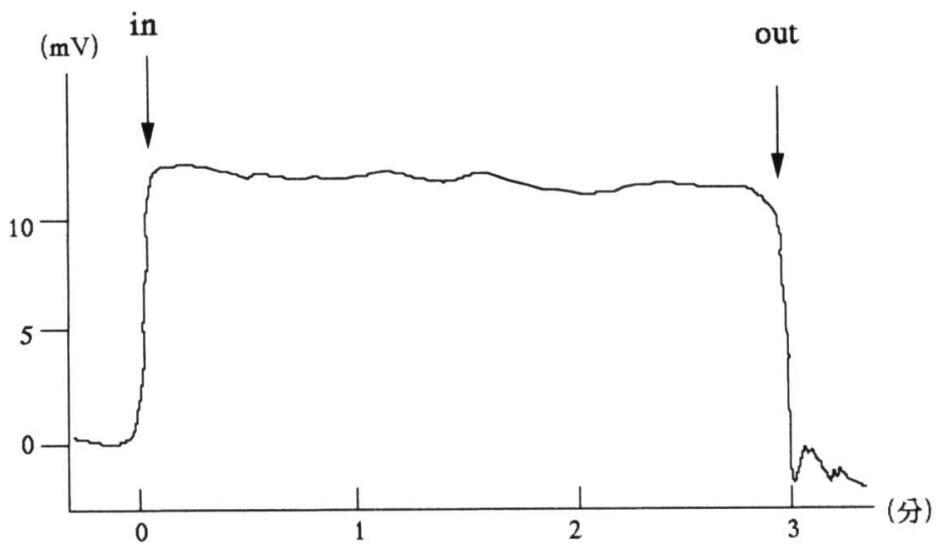

図2 内リンパ嚢直流電位（ESP）の測定波形

in (矢印) : 電極の刺入点, out (矢印) : 電極の抜去点。 
$\mathrm{EP}$ と若干の差異がみられる。ESP は酸素依存性 で anoxia 負荷により低下するが，EP とは異なり 正の電位で利尿剤フロセミド（furosemide）で低 下しない15)。また，その他の特徵として ESP は カテコールアミン (catecholamine) で低下する ことがよく知られている16)。Couloigner ら ${ }^{17)}$ は 1998年, 種々の薬剤に対する ESP の反応性につ いて詳細に検討し， $\mathrm{H}^{+}$-ATPase の阻害剂である bafilomycin $A_{1}$ p carbonic anhydrase の阻害剂であ る acetazolamide で ESP が抑制されることを報 告し，酸・塩基調節機構に依存した電位である 可能性を示唆している。最近, $\mathrm{H}^{+}$-ATPase の $\mathrm{B}_{1}$ subunit が内リンパ褧上皮に存在することが判明 し，この $\mathrm{B}_{1}$-subunit を翻訳する遺伝子 ATP6B1の 变異は難聴を伴ら筒尿細管アシドーシスを生じさ せることが報告された ${ }^{18)}$ 。また，内りンパ囊腔内 の内リンパが蝸牛・前庭とは異なり, 弱酸性 $(\mathrm{pH}$ =6.65）であることが知られて物り， $\mathrm{H}^{+}$-ATPase はこの内リンパ裹内の内リンパに拈ける $\mathrm{pH}$ 維持 とESP の発生機序に重要な因子と思われる ${ }^{199}$ 。 内耳に打ける内リンパの容量調節の観点よりみる と, Salt ら ${ }^{20)}$ は正円空より内リンパを注入ある いは吸引することで内りンパ腔の容積を変化さ せた際に，ESP が反応することを報告した。内

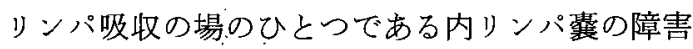
は，これまでメシェール病の病因として重要な要 素であると考えられ，実際に手術の対象にもなっ ている。ESPは，上述の動物実験における薬剤， 化学物質に対する反応性より，内リンパ囊の機能 を反映する電位と考えられる。今回，安定したヒ ト ESPが記録されたことより,我々の測定法は， メニエール病における内リンパ谼手術の際に応用 可能であると思われる。ESP を測定することに より, 電気生理学的見地よりメニエール病の内リ ンパ囊を評価することが可能であろう。

\section{まとめ}

1. 8 例の経迷路法による聴神経腫瘍摘出術術 中に内リンパ襄直流電位（ESP）を測定した。

2.8 例に和ける ESP の平均は $+13.3 \pm 1.9$ $\mathrm{mV}$ であった。全例形態学的には正常の内リンパ 蛮であり，測定値にばらつきが少ないことからこ の値はヒト ESP の正常値と考兄られた。

\section{文 献}

1) Guild SR: The circulation of endolymph. Am J
Anat 39: 57-81, 1927

2 ) Lundquist PG: The endolymphatic duct and sac in the guinea pig. An electron microscopic and experimental investigation. Acta Otolaryngol Suppl (Stockh) 201: 1-108, 1965

3) Tomiyama S, Harris JP: The endolymphatic sac: its importance in inner ear responses. Laryngoscope 96: 685-691, 1986

4) Qvortrup K, Rostgaard J, Holstein-Rathlou $\mathrm{NH}$ : The inner ear produces a natriuretic hormone. Am J Physiol 270: F1073-F1077, 1996

5) Rask-Andersen H, Erwall C, Steel KP, et al: The endolymphatic sac in a mouse mutant with cochleo-saccular degeneration. Electrophysiological and ultrastructural correlations. Hear Res 26: 177-190, 1987

6) Mizukoshi F, Bagger-Sjöbäck D, Rask-Andersen $\mathrm{H}$, et al: Cytochemical localization of $\mathrm{Na}^{+}, \mathrm{K}^{+}$ -ATPase in the guinea pig endolymphatic sac. Acta Otolaryngol (Stockh) 105: 202-208, 1988

7 ) Amano H, Orsulakova A, Morgenstern C: Intracellular and extracellular ion content of the endolymphatic sac. Arch Otorhinolaryngol 237: 273-277, 1983

8 ) Mori N, Uozumi N, Sakai S: Response of the endolymphatic sac d.c. potential to asphyxia. Acta Otolaryngol (Stockh) 111: 70-74, 1991

9) Ikeda K, Morizono T: The ionic and electric environment in the endolymphatic sac of the chinchilla: relevance of the longitudinal flow. Hear Res 54: 118-122, 1991

10) Schindler RA, Horn KL, Jones PL, et al: The ultrastructure of the endolymphatic sac in Meniere's disease. Laryngoscope 89: 95-106, 1979

11) Wackym PA: Histopathologic findings in $\mathrm{Me}-$ niere's disease. Otolaryngol Head Neck Surg 112: 90-100, 1995

12) Danckwardt-Lillieström N, Friberg U, Kinnefors A, et al: Ultrastructural analysis of 20 intraosseous endolymphatic sacs from patients with cerebellopontine angle tumors. A surgically obtained control material for histopathological studies. Auris Nasus Lerynx 27: 311- 
321,2000

13) Tsujikawa S, Yamashita T, Meyer zum Gottesberge AM, et al: Experimental interruption of the endolymphatic sac duct and its effect on the DC potential in the endolymphatic sac. Acta Otolaryngol (Stockh) 112: 785-790, 1992

14) Friberg U, Wackym $P$, Bagger-Sjöbäck $D$, et al: Effect of labyrinthectomy on the endolymphatic sac. A histological, ultrastructural and computer-aided morphometric investigation in the mouse. Acta Otolaryngol (Stockh) 101: 172 $-182,1986$

15) Mori N, Uozumi N, Yura $K$, et al: The difference in endocochlear and endolymphatic d.c. potentials in response to furosemide and canrenoate as diuretics. Eur Arch Otorhinolaryngol 247: 371-373, 1990

16) Mori N, Uozumi N, Sakai S: Catecholamines depress endolymphatic sac direct potential in guinea pigs. Am J Physiol: R921-R924, 1990

17) Couloigner V, Loiseau A, Sterkers $O$, et al: Effect of locally applied drugs on the endolym- phatic sac potential. Laryngoscope 108: 592598,1998

18) Karet EF, Finberg $\mathrm{KE}$, Nelson $\mathrm{RD}$, et al: $\mathrm{Mu}-$ tations in the gene encoding $\mathrm{B} 1$ subunit of $\mathrm{H}^{+}$-ATPase cause renal tubular acidosis with sensorineural deafness. Nat Genet 21: 84-90, 1999

19) Tsujikawa $S$, Yamashita $T$, Amano $H$, et al: Acidity in the endolymphatic sac fluid of guinea pigs. ORL 54: 198-200, 1992

20) Salt A, DeMott J: Ionic and potential changes of the endolymphatic sac induced by endolymph volume changes. Hear Res 149: 46-54, 2000

\footnotetext{
原稿到着：平成15年 5 月 21 日

別刷請求：隈上秀高

干852-8501 長崎市圾本 1-7-1

長崎大学医歯薬総合研究科病態解析制御学講座耳 鼻咽喉病態制御学領域

E-mail: h-kumagami@bun.bbiq.jp
} 